\title{
Determination of the L-DOPA (L-3, 4-Dihydroxyphenylalanine) Content in Faba Bean (Vicia faba L.) Flowers and Faba Bean Flower Tea
}

\author{
Hatice Bozoğlu ${ }^{1, a, *}$, Merve Bezmen ${ }^{2, b}$ \\ ${ }^{1}$ Department Field Crops, Agriculture Faculty, Ondokuz Mayis University, 55139 Samsun, Turkey \\ ${ }^{2}$ Department of Field Crops, Institute of Sciences, Ondokuz Mayls University, 55139 Samsun, Turkey
}

${ }^{*}$ Corresponding author

\begin{tabular}{|c|c|}
\hline ARTICLE INFO & A B S T R A C T \\
\hline $\begin{array}{l}\text { Received : 13/11/2020 } \\
\text { Accepted : 13/02/2021 }\end{array}$ & $\begin{array}{l}\text { This study aimed to determine the L-DOPA content in the flowers of some different faba bean } \\
\text { genotypes and determine the L-DOPA levels in tea prepared from flowers. The experiment was } \\
\text { carried out under the ecological conditions in Samsun by the Black Sea with } 15 \text { genotypes using a } \\
\text { randomized complete block design in three replications. The flowers were harvested three times and } \\
\text { the number of flowers and flower yields were determined. The L-DOPA content of the flower and } \\
\text { flower tea were determined using HPLC. Different solvents were used to extract the L-DOPA from } \\
\text { the faba bean flowers. As a result of the HPLC analyses, the highest L-DOPA yield was determined } \\
\text { to be in the tea samples brewed with hot water. It was found statistical differences between genotypes } \\
\text { in the second and third harvests for the number of flowers in the plant and the total number of flowers. } \\
\text { Dry flower yields ranged from } 11.33 \text { to } 37.78 \mathrm{~kg} \mathrm{da}^{-1} \text { while L-DOPA levels were } 6.2 \text { to } 9.17 \mathrm{~g} 100 \mathrm{~g}^{-1} \\
\text { in dry flowers and } 6.69 \text { to } 9.23 \mathrm{~g}^{-1} 100 \mathrm{~g}^{-1} \text { in infused tea. The study concluded that flower tea of faba } \\
\text { bean can be investigate for medicinal purposes and that L-DOPA in the plant can be extracted by } \\
\text { brewing without requiring any solvent. This shows that L-DOPA is in a salt form within the plant. }\end{array}$ \\
\hline
\end{tabular}

\section{Baklagillerde (Vicia faba L.) Çiçekler ve Bakla Fasulyesi Çiçek Çayında L-DOPA (L-3, 4-Dihidroksifenilalanin) İçeriğinin Belirlenmesi}

\begin{tabular}{|c|c|}
\hline M A K A L E B İ L G İ S İ & Ö Z \\
\hline $\begin{array}{l}\text { Anahtar Kelimeler: } \\
\text { L-DOPA } \\
\text { Bakla } \\
\text { Genotip } \\
\text { Çiçek } \\
\text { Çiçek çayı }\end{array}$ & $\begin{array}{l}\text { Bu çalışma, farklı bakla genotiplerinin çiçeklerinde ne kadar L-DOPA bulunduğu ve bu çiçeklerden } \\
\text { çay yapıldığında L-DOPA'nın çaya geçip geçmediğini belirlemek amaciyla yürütülmüştür. Deneme } \\
\text { Samsun ekolojik şartlarında } 15 \text { genotip kullanılarak } 3 \text { tekrarlamalı tesadüf blokları deneme deseninde } \\
\text { yürütülmüştür. Bitkilerde } 3 \text { kez çiçek hasadı yapılıp çiçek sayısı, çiçek verimleri belirlenmiştir. } \\
\text { Çiçekte ve çiçekten yapılan çayda L-DOPA miktarı HPLC ile tespit edilmiştir. Bakla çiçeklerinden } \\
\text { L-DOPA ekstraksiyonu için faklı çözücüler kullanılmış ve HPLC cihazıyla yapılan miktar } \\
\text { analizlerinde bakla çiçeklerinden kaynamış sıcak su ile çay hazırlandığında L-DOPA veriminin en } \\
\text { yüksek sıcak su ile demlenen ekstraktlarda olduğu belirlenmiştir. Yapılan varyans analizi sonucu } \\
\text { ikinci ve üçüncü hasatlardaki bitkide çiçek sayısı ile toplam çiçek sayısının genotiplerde istatistiki } \\
\text { olarak farklılık gösterdiği diğer incelenen özellikler arasında istatistiki fark olmadığı tespit edilmiştir. } \\
\text { Deneme ortalaması olarak kuru çiçek verimlerinin } 11,33-37,78 \mathrm{~kg} \text { da }{ }^{-1} \text {, kuru çiçeklerde } 6,2-9,17 \text {, } \\
\text { demlenerek elde edilen çiçek çayında } 6,69-9,23 \text { g 100g-1 L-DOPA olduğu tespit edilmiştir. Bu } \\
\text { çalışmada, bakla çiçek çayının tıbbi amaçla değerlendrilebileceği ve bitkideki L-DOPA'nın herhangi } \\
\text { bir çözücü gerektirmeden kaynar su ile demleme yapılarak ekstrakte edilebileceği sonucuna } \\
\text { varılmıştır. Bu durum L-DOPA'nın bitkide tuz formunda olduğunu da göstermektedir. }\end{array}$ \\
\hline
\end{tabular}




\section{Introduction}

Legumes are used for medicinal purposes due to their high antioxidant activity and polyphenol content as well as being a source of protein (Vioque et al., 2012). The faba bean has the strongest growth properties and nitrogen fixing capacity among edible legumes (Akçin, 1988). Therefore, especially in temperate climates, it can be grown in winter and yield fruit in early spring, which leaves enough time for another crop to grow. Sepetoglu (1994) stated that the widely cultivated faba bean varieties have strong apical dominance and indeterminate growth habits; therefore, the plant has a very high flowering potential. Topal (2005), in a two-year study carried out in Samsun, reported that the average number of flowers per plant in the first year was 23.54, in the second year it was 49.61 and he stated that 9.08 to $31.48 \%$ of the flowers were capable of setting pods. These data show that although the plant blooms in large numbers, most of it is shed, that is, a large part of the plant's energy is lost.

The faba bean is rich in proteins, complex carbohydrates, dietary fiber, choline, lecithin, minerals and secondary metabolites (Mohseni and Golshani, 2013; Etemadi et al., 2015). The faba bean accumulates a large amount of LDOPA, a precursor to dopamine that is currently used in treating Parkinson's disease (PD). More than 30 years after its development, L-DOPA is still the most effective, multifunctional prodrug for treatment of the symptoms of Parkinson's disease. Although several therapies have been developed in an attempt to improve PD management, most patients still depend on levodopa alone because of its superior ability to control the symptoms of PD (Lewitt and Nyholm, 2004; Aurizio et al., 2011). L-DOPA is synthesized from the amino acid L-tyrosine in the mammalian body and brain (Randhir and Shetty 2004). Synthesized L-DOPA is expensive and often causes a variety of side effects including nausea, vomiting, low blood pressure, drowsiness and restlessness (Patil et al., 2013). For this reason, the use of natural sources of L-DOPA to avert potential side effects has been recommended (Etemadi et al., 2018). Hu et al. (2015) declared that the average L-DOPA concentration, based on dry weight (DW) in flowers, ranged from 27.8 to $63.5 \mathrm{mg} \mathrm{g}$ 1. The study found a variation of L-DOPA concentration from 18.2 to $48.7 \mathrm{mg} \mathrm{g}^{-1}$ in the leaf tissues of six faba bean lines with common and rare flower colors to provide the necessary information for people who want to use faba beans as a natural remedy or functional food to relieve PD symptoms. Also, they stated that faba beans have the potential to be developed as a functional food crop for PD patients. Consumption of young pods and leaves is the most practical means for direct intake or processing of L-DOPA from the faba bean plant. In Turkey, the most common use of faba bean for PD is fresh fruit. Topal and Bozoğlu (2016) conducted a study to determine the L-DOPA content of leaf, flower and fresh fruits of faba bean genotypes in Samsun and found that the average L-DOPA content to be 19.36, 75.87 and $25.27 \mathrm{mg} \mathrm{kg}^{-1}$ in the leaves, flowers and fruits, respectively. Consequently, the content of L-DOPA in the flower was higher than that in the leaf and the fruit. Based on this information, this study was carried out to determine whether the flowers in faba bean plants capable of forming a large number of flowers- can be used for their high LDOPA content.

\section{Materials and Methods}

The trial was carried out in Samsun province located on the Black Sea coast of Turkey. The trial area was determined to be clayly with a neutral $\mathrm{pH}$ (6.887), salt-free $\left(\mathrm{EC}=0.523 \mathrm{dS} \mathrm{m}^{-1}\right)$, with moderate organic matter (2.681\%) and a rich phosphorus content (64.333 ppm P). A humid and temperate climate is dominant in Samsun. The average rainfall during the plant growing period was $537 \mathrm{~mm}$ and $613 \mathrm{~mm}$ in the period when the trial was carried out. It was in line with the long-term period average over the remaining months the experiment was conducted.

A total of 15 genotypes, including 3 registered varieties (Lara, Seher and Eresen-87) and 12 lines were used in the experiment. While Lara and Seher, which were selected as the control groups, are the varieties used for fresh consumption, Eresen-87 is used for dry seed. The experiment was conducted using the randomized completely blocks desing with three replications over the 2016 to 2017 growing season. Sowing was carried out on 21 November with $50 \times 10 \mathrm{~cm}$ plant density. The experiment was carried out under non-fertilized conditions. The flowers were harvested three times (20 April, 27 April and 5 May) at one-week intervals from marked plants on each plot to detrermine the yield flower of a plant at each harvest, the number of flowers was determined, then weighed and dried to calculate the total number of flowers per plant, and the weight and dry flower yield per decare.

L-DOPA analyses of the dry flower samples were performed according to Etemadi et al. (2018) using highperformance liquid chromatography (HPLC) with $0.1 \mathrm{~N}$ of $\mathrm{HCl}$ as the solvent. The method was modified for the tea samples made from flowers. Accordingly, $100 \mathrm{mg}$ of dried, faba bean flowers was added into $50 \mathrm{ml}$ volumetric flasks, and freshly boiled deionized water was added and the mixture was then brewed for close to 15 minutes to obtain the flower tea. The chromatographic conditions (Agilent 1260 HPLC device with an ACE $150 \times 4.6$ mm 155-micron C18 column, a UV detector, a $283 \mathrm{~nm}$ detector wavelength, $1 \mathrm{ml}$ of acetic acid, $20 \mathrm{ml}$ of methanol and $979 \mathrm{ml}$ of deionized water mixture mobile phase and a $1 \mathrm{ml} \mathrm{min}^{-1}$ flow rate) were used for both sample groups. To calculate the amount of L-DOPA in the samples, a $1000 \mathrm{ppm} \mathrm{L-}$ DOPA standard stock solution was prepared and the standard solution doses were diluted to concentrations of $100,200,300,400,500 \mathrm{ppm}$. The five different concentrations of standard solution were then injected into the HPLC device and the peak areas (Figure 1) were plotted against concentration to form a calibration table. Analysis of variance was performed using SPSS-21 software and DUNCAN's multiple comparison test was used to compare the means accordingly $(\mathrm{P}<0.05)$.

\section{Results and Discussion}

\section{The number of Flowers and Yield}

The faba bean showed unlimited growth properties and can bloom with a large number of flowers, or has a high potential to bloom (Sepetoğlu, 1994). It has been reported that 62 to $80 \%$ of the flower blooms and 67 to $88 \%$ were shed failed to bloom after pollination under the changing environmental conditions (Bozoğlu, 2005). The flower observations obtained from three different harvests are given 
in Table 1. The average for the experiment was determined to be 62.56 flowers per plant. In a study conducted in the same location, the number of flowers per plant was reported to vary between 9 and 279 (Topal and Bozoglu2006). This difference may be due to the differences in the genotype and climatic data of the years in which the experiments were conducted. In the present study, a statistically significant difference $(\mathrm{P}<0.01)$ was found between genotypes in terms of the total number of flowers (Table 1). The $\mathrm{G}_{12}$ genotype, which has the highest number of flowers (121 flowers) was statistically different to all other genotypes except for the $\mathrm{G}_{9}$ genotype. There was no statistical difference between genotypes in terms of flower weights over the three harvests. The first flower harvest was carried out on 20 April, and the average number of flowers per plant ranged from 16.47 to 47.11. The genotype $\mathrm{G}_{12}$ had the highest number of flowers. The same genotype gave the highest number of flowers in the other harvests.

The number of flowers in the second harvest ranged from 9.2 to 27.8 . The $\mathrm{G}_{12}$ genotype yielded the highest number of flowers in the second harvest while one of the control varieties Eresen-87 was in the same group with $\mathrm{G}_{2}$ and $\mathrm{G}_{15}$. In the third harvest, the number of flowers in the different genotypes varied between 7 and 46, and this change was statistically significant.

Examining the ratio of harvests to the total number of flowers, it was seen that the first harvest contributed 39\%, the second harvest contributed $24 \%$ and the last harvest contributed 38\%; however, these ratios changed according to the genotypes in each harvest (Figure 1). The Seher variety, produced $64 \%$ of the total flowers while the Lara variety produced $41 \%$ of the flowers in the first harvest (Figure 1). $\mathrm{G}_{14}$ and $\mathrm{G}_{8}$ genotypes achieved the highest rates in the last harvest. This change also provided us with information about how early or late the plants bloomed. While early yield varieties gave more flowers in the first harvest, the number of flowers increased in the last harvest for the late yield varieties. In this study, flowers were collected at one-week intervals. The average for the experiment, dry matter values for the collected flowers were deterimened $13 \%$, it was determined that this ratio did not change statistically across genotypes.

As a result of variance analysis, no statistically significant difference was found between genotypes in terms of dry flower weight (Table 2). The dry flower weights of the genotypes per decare ranged from 14.00 to $27.11 \mathrm{~kg}$.

Climatic requirements and soil reclemation characteristics make the plant one of the most indispensable crops to plant in temperate climate regions. Therefore, it is an important plant for the farmer due to its improvement of the soil and to take part in crop rotation. It is also an important plant in terms of health and nutrition. Nowadays, consumer food demand is affected not just by taste but by the health benefits of the food. Faba beans, as well as being a rich source of protein, is a product whose potential demand may increase due to the L-DOPA it contains.

\section{L-DOPA value}

$\mathrm{PD}$ is the second most common neurodegenerative disorder characterized by the loss of muscle control (Hu et al., 2015). L-DOPA is a non-protein compound with a strong allelopathic effect, which attracts attention due to its inhibitory effect on PD and is found in Mucuna pruriens and faba beans (Soares et al., 2014). Mucuna is not grown in Turkey. The faba bean originates from the region that includes Anatolia and is an important L-DOPA source (Topal and Bozoğlu, 2016). Lattanzio et al. (1983) reported that L-DOPA was found in faba beans with 1.4 to $4.9 \%$ in the leaves and $4 \%$ in the pod. In Turkey, the most common form of consumption of faba beans for use in traditional medicine for PD is through the consumption of fresh fruits. In a study conducted in Samsun, the L-DOPA content was found to be $19.36,75.87$ and $25.27 \mathrm{mg} \mathrm{kg}^{-1}$ in leaves, flowers and fruits, respectively, with the highest value detected in the flowers (Topal and Bozoğlu, 2016). The flowering time and the number of flowers of the plant show additive heritability (K1t1k1 and Demir, 1984) and can bloom in large numbers; however, they shed most of their yield with a significant loss of energy. This led us to the idea that flowers can be used differently, such as in making tea.

In this study, the L-DOPA content was determined in the flowers and tea made from the flowers. The amount of L-DOPA in the genotypes used, ranged from 6.85 to $8.38 \mathrm{~g}$ per $100 \mathrm{~g}$ (Table 2). As a result of variance analysis, no statistically significant difference was found between genotypes in terms of the L-DOPA value. However, the highest L-DOPA Lara variety was observed in the DUNCAN grouping and it was found to differ from the $\mathrm{G}_{2}$ and $\mathrm{G}_{15}$ lines $(\mathrm{P}<0.05)$. Pugalenthi et al. (2005) reported LDOPA at $1 \%$ in leaves Lattonzia et al. (1983) founded $4 \%$. Teixeira et al. (2003) reported that 0.2 to $0.5 \%$ of the dry matter was L-DOPA. Etemadi et al. (2018) declared that the highest L-DOPA content was detected in fresh leaves $\left(22.4 \mathrm{mg} \mathrm{g}^{-1}\right)$ followed by the flowers, young pods, mature seeds and roots. The L-DOPA concentration in faba bean tissues was significantly reduced when the tissues were boiled or dried. Some different results have been encountered in published literature. It is thought that these differences were due to the differences between the genotypes used, the environment in which the plants were grown and especially in the detection method.

Capo-Chichi et al. (2003) determined the effect of environmental conditions on the L-DOPA on the Mucuna. Among various methods of processing, freezing had the least detrimental effect. Hu et al. (2015) declared that ideally, the genotype with the highest average L-DOPA concentration in both flowers and leaves could be grown as a natural source of this medicinally important amino acid. When developing faba beans as a functional food crop for PD patients, a careful selection of genotype seems necessary to exploit the full potential of this natural remedy.

The flowers of many plants in Turkey are used as tea for various reasons. Due to the ability of the faba bean to produce a large number of flowers, for the first time in Turkey it was investigated in the form of tea, based on the hypotheses that the flowers can be brewed into a drink. In the preliminary experiments to determine L-DOPA levels in tea, the highest yield was obtained with boiled water as a solvent for extraction. Therefore, boiling water was used for the L-DOPA analysis in tea. The average L-DOPA value in the infused flower tea was found to be

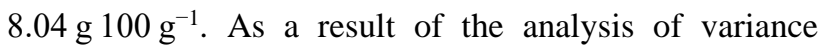
between the genotypes, there were no differences in LDOPA (Table 2). 
Table 1. Mean of flowers harvest observation at the faba bean genotypes

\begin{tabular}{|c|c|c|c|c|c|c|}
\hline \multirow{3}{*}{ Genotype } & \multicolumn{6}{|c|}{ Flowers Properties /per plant } \\
\hline & \multicolumn{2}{|c|}{ First Harvest } & \multicolumn{2}{|c|}{ Second harvest } & \multicolumn{2}{|c|}{ Third harvest } \\
\hline & $\begin{array}{c}\text { Number of } \\
\text { flower }\end{array}$ & $\begin{array}{c}\text { Dry weight of } \\
\text { flowers }(\mathrm{g})\end{array}$ & $\begin{array}{l}\text { Number of } \\
\text { flower** }\end{array}$ & $\begin{array}{l}\text { Dry weight of } \\
\text { flowers }(\mathrm{g})\end{array}$ & $\begin{array}{l}\text { Number of } \\
\text { flower* }\end{array}$ & $\begin{array}{l}\text { Dry weight of } \\
\text { flowers }(\mathrm{g})\end{array}$ \\
\hline Eresen-87 & $25.44^{\mathrm{b}}$ & 7.03 & $19.44^{\mathrm{abc}}$ & 1.26 & $26.77^{\mathrm{abc}}$ & 3.69 \\
\hline $\mathrm{G}_{2}$ & $22.78^{\mathrm{b}}$ & 5.48 & $17.77^{\mathrm{a}-\mathrm{d}}$ & 1.22 & $31.88^{\mathrm{ab}}$ & 4.18 \\
\hline $\mathrm{G}_{3}$ & $27.89^{\mathrm{b}}$ & 3.68 & $10.66^{\mathrm{cd}}$ & 2.65 & $34.33^{\mathrm{ab}}$ & 6.50 \\
\hline $\mathrm{G}_{4}$ & $18.11^{\mathrm{b}}$ & 3.53 & $12.22^{\mathrm{cd}}$ & 1.76 & $22.44^{\mathrm{bc}}$ & 3.11 \\
\hline $\mathrm{G}_{5}$ & $17.66^{\mathrm{b}}$ & 7.11 & $9.33^{\mathrm{cd}}$ & 1.96 & $13.55^{\mathrm{bc}}$ & 3.15 \\
\hline $\mathrm{G}_{6}$ & $21.89^{\mathrm{b}}$ & 5.00 & $14.00^{\mathrm{bcd}}$ & 2.64 & $14.33^{\mathrm{bc}}$ & 2.60 \\
\hline Seher & $29.44^{\mathrm{b}}$ & 4.80 & $7.45^{\mathrm{d}}$ & 2.18 & $12.33^{\mathrm{bc}}$ & 4.94 \\
\hline $\mathrm{G}_{8}$ & $19.33^{\mathrm{b}}$ & 5.12 & $9.21^{\mathrm{cd}}$ & 1.10 & $33.77^{\mathrm{ab}}$ & 5.36 \\
\hline $\mathrm{G}_{9}$ & $24.32^{\mathrm{b}}$ & 5.56 & $16.66^{\mathrm{bcd}}$ & 2.75 & $32.87^{\mathrm{ab}}$ & 5.13 \\
\hline $\mathrm{G}_{10}$ & $21.32^{\mathrm{b}}$ & 5.03 & $15.32^{\mathrm{bcd}}$ & 2.97 & $24.78^{\mathrm{abc}}$ & 2.28 \\
\hline Lara & $16.22^{\mathrm{b}}$ & 4.41 & $15.75^{\mathrm{bcd}}$ & 1.54 & $7.55^{\mathrm{c}}$ & 3.64 \\
\hline $\mathrm{G}_{12}$ & $47.11^{\mathrm{a}}$ & 4.50 & $27.77^{\mathrm{a}}$ & 2.30 & $46.00^{\mathrm{a}}$ & 5.85 \\
\hline $\mathrm{G}_{13}$ & $27.44^{\text {cde }}$ & 6.13 & $11.97^{\mathrm{cd}}$ & 2.52 & $17.54^{\mathrm{bc}}$ & 4.32 \\
\hline $\mathrm{G}_{14}$ & $19.11^{\mathrm{b}-\mathrm{e}}$ & 3.53 & $11.00^{\mathrm{cd}}$ & 3.12 & $25.44^{\mathrm{abc}}$ & 4.47 \\
\hline $\mathrm{G}_{15}$ & $24.10^{\mathrm{ab}}$ & 3.90 & $24.65^{\mathrm{ab}}$ & 3.52 & $20.43^{\mathrm{bc}}$ & 4.61 \\
\hline Mean & 24.14 & 5.07 & 14.88 & 2.14 & 24.27 & 4.19 \\
\hline Genotype & \multicolumn{3}{|c|}{ Total number of flowers** } & \multicolumn{3}{|c|}{ Total weight of flowers $\left(\mathrm{g} \mathrm{plant}^{-1}\right)$} \\
\hline Eresen-87 & & $71.66 \mathrm{ab}$ & & & 11.99 & \\
\hline $\mathrm{G}_{2}$ & & $72.66 \mathrm{ab}$ & & & 10.88 & \\
\hline $\mathrm{G}_{3}$ & & $71.00 \mathrm{ab}$ & & & 12.83 & \\
\hline $\mathrm{G}_{4}$ & & $56.66 \mathrm{~b}$ & & & 8.40 & \\
\hline $\mathrm{G}_{5}$ & & $41.00 \mathrm{~b}$ & & & 12.22 & \\
\hline $\mathrm{G}_{6}$ & & $50.33 \mathrm{~b}$ & & & 10.22 & \\
\hline Seher & & $46.00 \mathrm{~b}$ & & & 11.90 & \\
\hline $\mathrm{G}_{8}$ & & $62.33 \mathrm{~b}$ & & & 11.57 & \\
\hline $\mathrm{G}_{9}$ & & $73.66 \mathrm{ab}$ & & & 13.44 & \\
\hline $\mathrm{G}_{10}$ & & $61.33 \mathrm{~b}$ & & & 10.27 & \\
\hline Lara & & $39.33 \mathrm{~b}$ & & & 9.60 & \\
\hline $\mathrm{G}_{12}$ & & $121.00 \mathrm{a}$ & & & 12.64 & \\
\hline $\mathrm{G}_{13}$ & & $57.00 \mathrm{~b}$ & & & 13.00 & \\
\hline $\mathrm{G}_{14}$ & & $50.33 \mathrm{~b}$ & & & 11.12 & \\
\hline $\mathrm{G}_{15}$ & & $64.00 \mathrm{~b}$ & & & 12.01 & \\
\hline Mean & & 62.56 & & & 11.41 & \\
\hline
\end{tabular}

Table 2. Mean of some flower properties of faba bean genotypes $* \mathrm{P}<0.05$.

\begin{tabular}{|c|c|c|c|c|}
\hline Genotype & $\begin{array}{l}\text { Ratio of dry matter in flower } \\
(\%)\end{array}$ & $\begin{array}{l}\text { Yield of dry flower } \\
\qquad\left(\mathrm{kg}-{ }^{-1} \mathrm{da}\right)\end{array}$ & $\begin{array}{l}\text { L-DOPA in flower } \\
\qquad\left(\mathrm{g} 100 \mathrm{~g}^{-1}\right)\end{array}$ & $\begin{array}{l}\text { L-DOPA in flower tea } \\
\qquad\left(\mathrm{g} 100 \mathrm{~g}^{-1}\right)\end{array}$ \\
\hline Eresen-87 & 12.64 & 19.70 & $8.21^{\mathrm{abc}}$ & $7.82^{\mathrm{ab}}$ \\
\hline $\mathrm{G}_{2}$ & 13.41 & 19.85 & $7.31^{\mathrm{bc}}$ & $8.00^{\mathrm{ab}}$ \\
\hline $\mathrm{G}_{3}$ & 19.06 & 27.11 & $7.76^{\mathrm{abc}}$ & $8.56^{\mathrm{a}}$ \\
\hline $\mathrm{G}_{4}$ & 11.47 & 16.29 & $7.86^{\mathrm{abc}}$ & $8.16^{\mathrm{ab}}$ \\
\hline $\mathrm{G}_{5}$ & 14.69 & 17.92 & $7.81^{\mathrm{abc}}$ & $8.27^{\mathrm{ab}}$ \\
\hline $\mathrm{G}_{6}$ & 13.00 & 20.88 & $7.84^{\mathrm{abc}}$ & $8.20^{\mathrm{ab}}$ \\
\hline Seher & 15.45 & 18.81 & $7.54^{\mathrm{abc}}$ & $8.11^{\mathrm{ab}}$ \\
\hline $\mathrm{G}_{8}$ & 13.08 & 20.22 & $8.05^{\mathrm{abc}}$ & $8.33^{\mathrm{ab}}$ \\
\hline $\mathrm{G}_{9}$ & 12.19 & 22.00 & $8.02^{\mathrm{abc}}$ & $8.42^{\mathrm{ab}}$ \\
\hline $\mathrm{G}_{10}$ & 13.50 & 23.85 & $7.44^{\mathrm{abc}}$ & $7.65^{\mathrm{ab}}$ \\
\hline Lara & 15.17 & 14.00 & $8.38^{\mathrm{a}}$ & $8.25^{\mathrm{ab}}$ \\
\hline $\mathrm{G}_{12}$ & 13.71 & 23.48 & $7.77^{\mathrm{abc}}$ & $7.73^{\mathrm{ab}}$ \\
\hline $\mathrm{G}_{13}$ & 13.53 & 19.22 & $7.81^{\mathrm{abc}}$ & $7.41^{\mathrm{b}}$ \\
\hline $\mathrm{G}_{14}$ & 11.59 & 21.33 & $7.56^{\mathrm{abc}}$ & $7.38^{\mathrm{b}}$ \\
\hline $\mathrm{G}_{15}$ & 13.94 & 21.48 & $6.85^{\mathrm{c}}$ & $8.34^{\mathrm{ab}}$ \\
\hline Mean & 13.80 & 20.40 & 7.74 & 8.04 \\
\hline
\end{tabular}




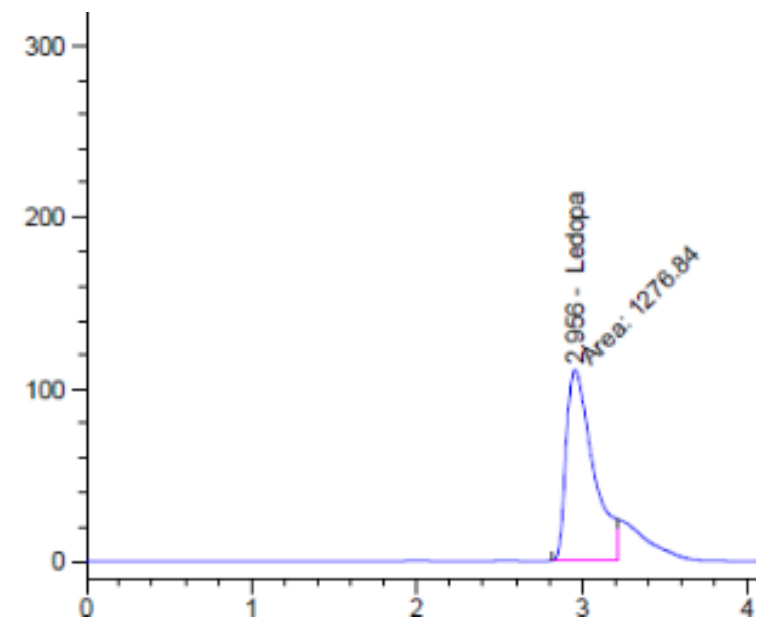

a) 100 microlitre

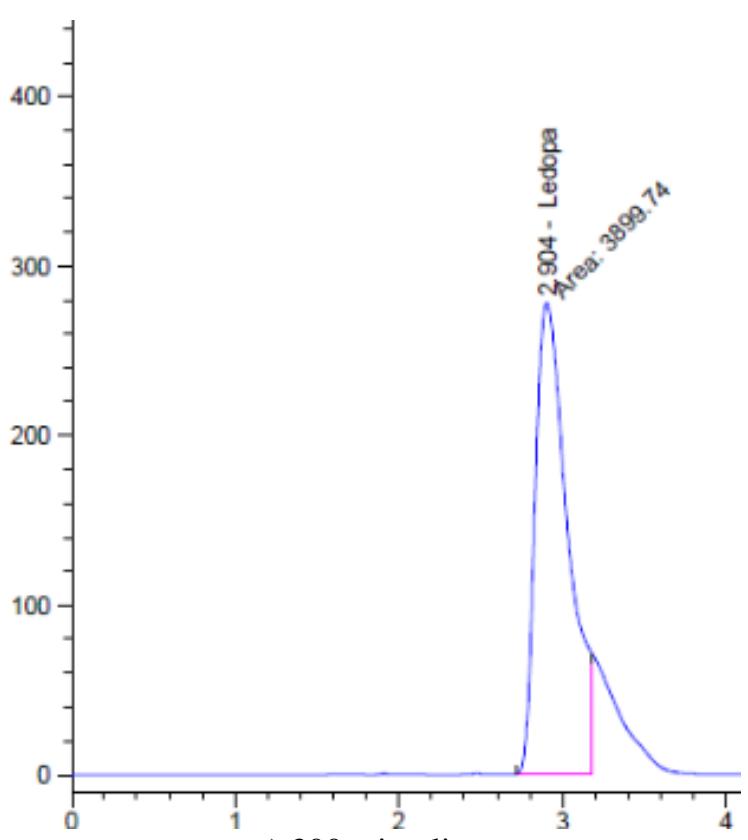

c) 300 microlitre

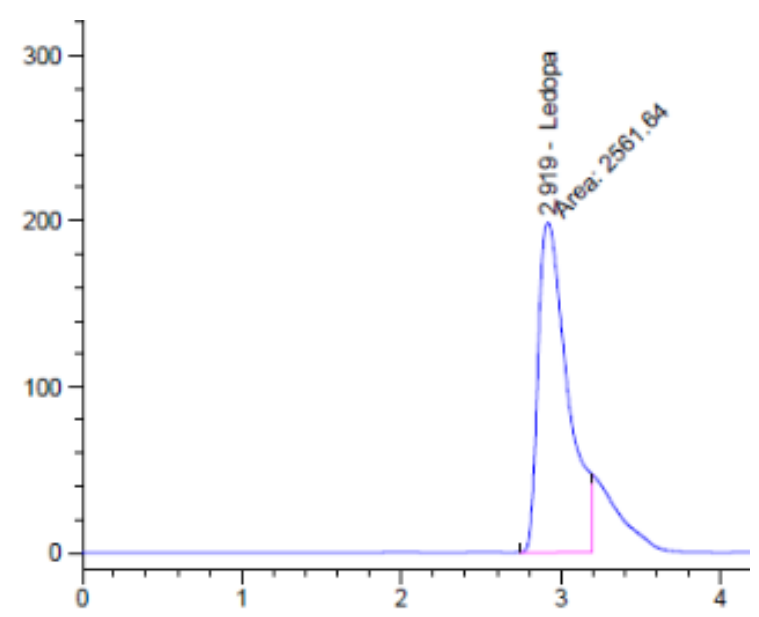

b) 200 microlitre

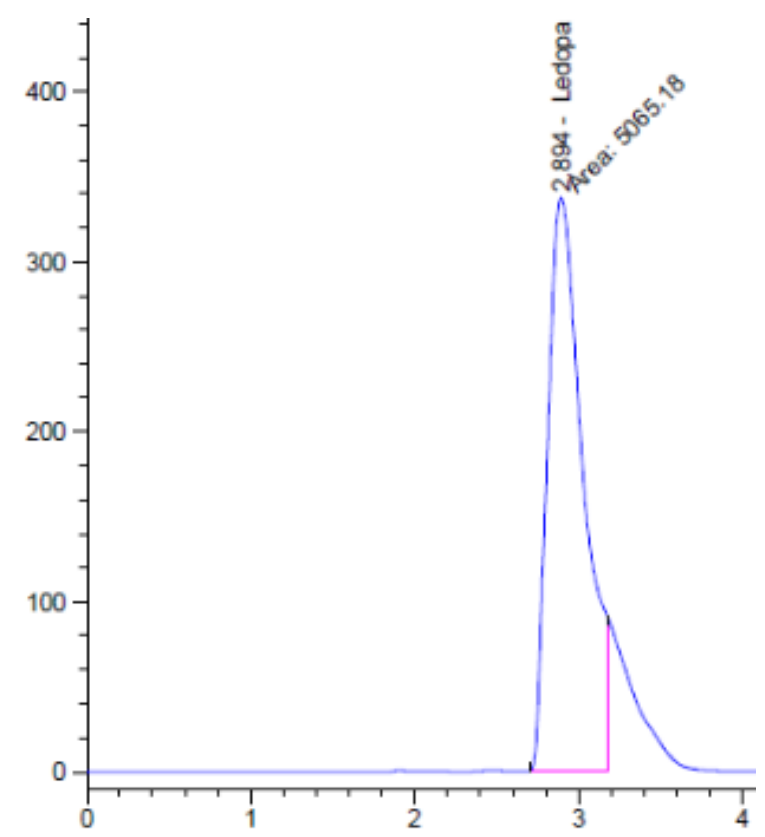

d) 400 microlitre

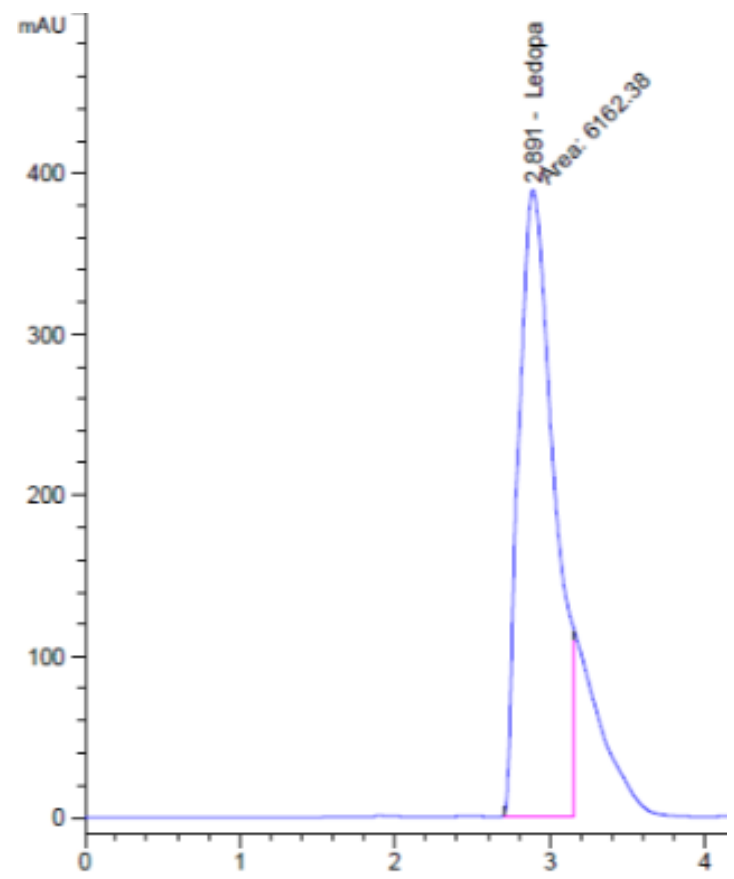

e) 500 microlitre

Figure 1. Pikes of the L-DOPA standart doses 


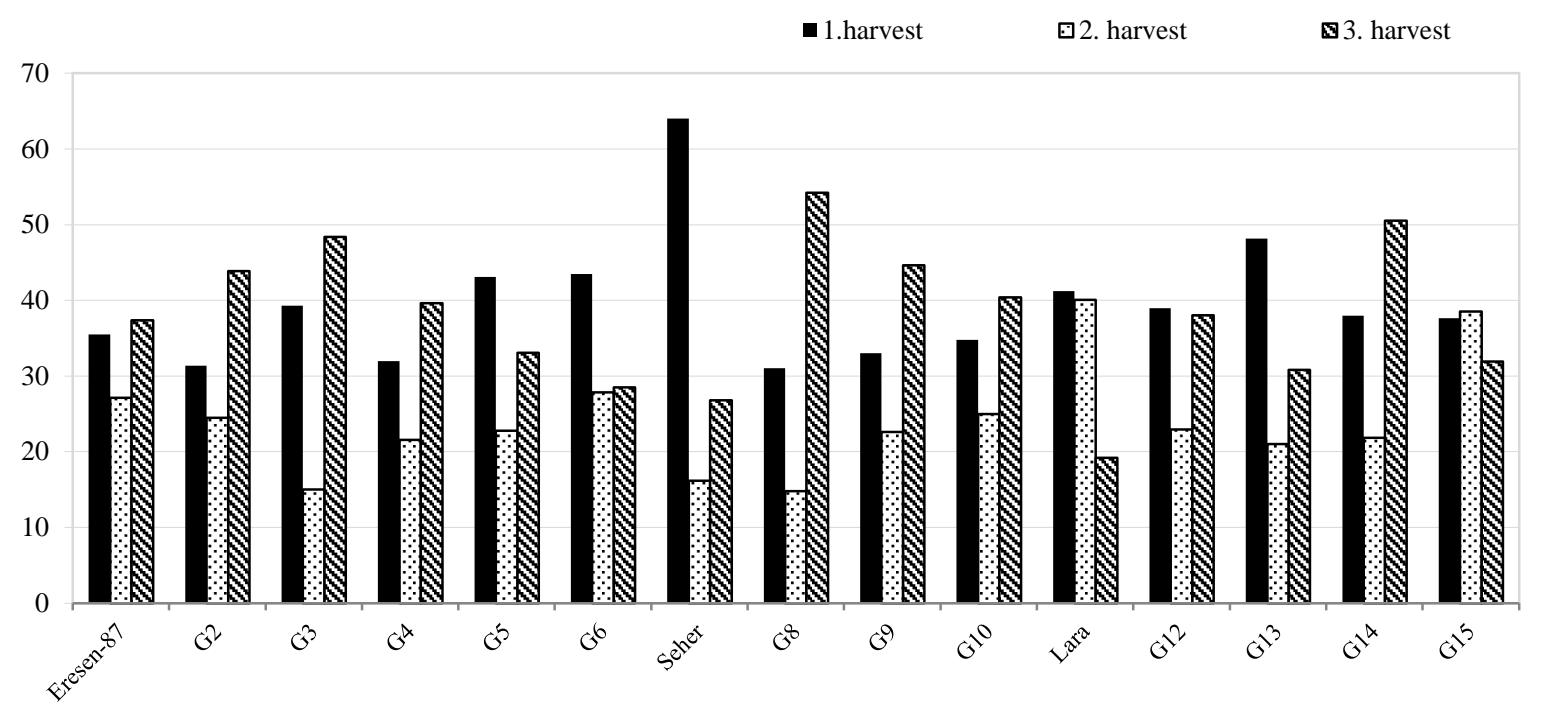

Figure 2. Ratio of flower numbers of faba bean genotypes on the different harvest time

According to DUNCAN's multiple comparison test using a $5 \%$ probability, $\mathrm{G}_{3}$ (Samsun-Merkez) produced the highest value and was included in the same statistical group as the other lines, except for the $G_{13}$ and $G_{14}$ lines that originated from ICARDA (Table 2). This showed that these were promising for our future studies.

To increase the consumption of a product, it is necessary to increase their important nutritional and health quality properties. The faba bean is a good example of this. All over the world, the incidence of PD increases with age, while the demand for healthier treatment methods increases as knowledge increases. Faba beans are among the plants with a high potential for use as a functional food in the treatment of PD. Turkey is a very rich country in terms of traditional medicinal plants and their use in medicine; however, there are not enough studies on LDOPA. This study will help to close this gap.

In this study carried out with 15 faba bean genotypes, L-DOPA was investigated only in the flowers and in herbal tea produced from the flowers. The average number of flowers per plant was 62.56 after 3 harvests and the total number of flowers per plant in the genotypes ranged from 33.3 to 121 in these genotypes (Figure 2). Taking the number of pods into consideration, it was found that the pod setting ratio varied between 13.71 to $36.06 \%$ in the genotypes and the rest of the flowers were shed.

Dried flower yield per decare was determined to be $20.4 \mathrm{~kg}$ by the average for the experiment. The $\mathrm{G}_{3}$ line collected from Samsun was the most productive genotype in terms of flower yield. This data will increase in importance when flowers with a L-DOPA content are used for health reasons. The L-DOPA content, which constitutes the most striking side of the present study, was determined to be an average of $7.74 \mathrm{~g}$ per $100 \mathrm{~g}$ of dry flower in the experiment. Calculated from the average dry flower yield, the L-DOPA yield per decare was approximately $1.6 \mathrm{~kg}$. These results were higher than some of the results in published literature and lower than others. We believe that these differences occurred according to the ecological conditions in which the plant was grown and the chemical analysis method adopted. The climatic data of the year in which the experiment was conducted did not show much difference compared to the long-term average for the region and did not become a factor that would cause stress in the growing plant.

Turkey has a rich herbal biological diversity, and the traditional use of these herbs are quite common. One of these involves the use of different parts of different plants, especially flowers, as tea. The presence of L-DOPA in faba bean flowers and the herbal tea culture in Turkey helped create the hypothesis that faba bean flowers can be brewed, and it was found that faba bean flower tea contained LDOPA. The average L-DOPA value in the infused flower

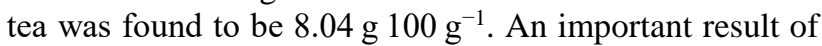
this study was that L-DOPA can be extracted by brewing with boiling water and did not require any solvent. LDOPA is in salt form in the plant and it can be measured directly without the use of any chemical solutions. The fact that the results obtained from tea and from dried flower samples were close to each other proved this result. In coastal regions in Turkey, the faba bean can be easily cultivated during winter and it can be cultivated in early spring in other parts of the country. The public should be informed more widely that the faba bean is an important source of L-DOPA, that their flowers can be used as a tea and are effective in the treatment against Parkinson's. Future studies should focus on determining the L-DOPA contents in teas obtained from faba bean flowers harvested over the same growth period, with different dry matter contents and with different brewing times. Furthermore, animal studies should be conducted focusing on the treatment of the disease.

\section{Acknowledgement}

This study is part of Merve Bezmen's Master of Science Thesis completed in the june 2019. The authors sincerely thank Dr. İbrahim Bulduk of Uşak University, School of Health for his assistance in chemical analysis of this study

\section{References}

Akçin A. 1988. Yemeklik Tane Baklagiller. Selçuk Üni.Yayınları:43, Zir. Fak. Yayınları: 8. Konya (in Turkish). 
Aurizio ED, Nostrum CF, Steenbergen MJ, Sozio P, Siepmann F, Siepmann J, Hennink WE, Di Stefano A. 2011. Preparation and characterization of poly (lactic-co-glycolic acid) microspheres loaded with a labile antiparkinson prodrug. International Journal of Pharmaceutics, Vol 409, Issues 1-2, 16 May 2011, Pages 289-296.

Bozoğlu H. 2005. Baklada (Vicia faba L.) Çiçeklenme ve meyve bağlama durumlarının tespiti ve tane verimiyle ilişkileri. Türkiye VI. Tarla Bitkileri Kongresi. 5-9 Eylül 2005, Cilt II. Sayfa 637-642, Antalya. (in Turkish with an abstract in English)

Capo-Chichi LJA, Eilitta M, Carsky RJ, Gilbert RA, Maasdorp B. 2003. Effect of genotype and environment on L-DOPA concentration in Mucuna's (Mucuna sp.) seeds. Tropical and Subtropical Agroecosystems, 1: $319-328$.

Etemadi F, Hashemi M, Xing B, Mashayekhi H, Randhir R, Jahanzad E. 2015. Faba Beans a rich natural source of L-Dopa for parkinson disease. Crops. Dairy. Livestock. Equine Newsletter. UMass Extension 18:1.

Etemadi F, Hashemi M, Randhir RZ, Vakili O, Ebadi A. 2018. Accumulation of L-DOPA in various organs of faba bean and influence of drought, nitrogen stress and processing methods on L-DOPA yield. The Crop Journal Vol.6, Issue 4: 426-434.

Hu JG, Kwon SJ, Park JJ, Landry E, Mattinson DS, Gang DR. 2015. LC-MS determination of L-DOPA concentration in the leaf and flower tissues of six Faba Bean (Vicia faba L.) lines with common and rare flower colors. Functional Foods in Health and Disease, Volume5, Issue 7, Pages 243-250.

Kıtıkı A, Demir İ. 1984. Baklada diallel çaprazlama yöntemiyle verim bileşenlerinin ve kalıtımlarının $F 1$ ve F2 generasyonlarında saptanması. Ege Üni. Zir. Fak. Dergisi.1984, 21/2 (167-177) İzmir.

Lattanzio V, Bianco V, Crivelli G, Miccolis V. 1983. Variability of amino acids, protein, vicine and convicine in Vicia faba $(\mathrm{L})$ cultivars. Journal of Food Science vol. 48 Issue 3 Page 992993.

Lewitt PA, Nyholm D. 2004. New developments in Levodopa therapy. Neurology. 13;62(1 Suppl 1):9-16.
Patil SA, Apine OA, Surwase SN, Jadhav JP. 2013. Biological sources of L-DOPA: an alternative approach. Advenced Parkinson's Disease. 2: 81-87 BC

Mohseni MSM, Golshani B. 2013. Simultaneous determination of Levodopa and carbidopa from faba bean green peas and green beans by high performance liquid gas chromatography. Journal of Clinical and Diagnostic Research for Doctors 7:1004-07.

Pugalenthi M, Vadivel V, Siddhuraju P. 2005. Alternative Food/Feed Perspectives of An Underutilized Legume, Mucuna Pruriens Var. Utilis-A Review. Plant Foods for Human Nutrition; 60:201-18; Pmid:16395632

Randhir R, Shetty K. 2004. Microwave-induced stimulation of LDOPA. Phenolics and antioxidant activity in fava bean (Vicia faba) for Parkinson's diet. Process Biochemistry, 39:1775-1784.

Sepetoğlu H. 1994. Yemeklik Tane Baklagiller. Ege Uni. Zir. Fak. Yayınları Ders Notları no:24, İzmir, 262 s (in Turkish).

Soares AR, Marchiosi R, Siqueira-Soares R de C, Barbosa de Lima R, Dantas dos Santos W, Ferrarese-Filho O. 2014. The role of L-DOPA in plants. Plant Signaling and Behavior 9(3): 28275; March

Teixeira AA, Rich EC, Szabo NJ. 2003. Water Extraction of LDOPA from Mucuna bean. Tropical and Subtropical Agroecosystems, 159 - 171.

Topal N. 2005. Bakla (Vicia faba L.)'da tepe ve dal almanın çiçek, bakla tutumu ve tane verimine etkileri. OMÜ Fen Bil. Ens, Yük Lis.Tezi, Basılmamış (in Turkish with an abstract in English)

Topal N, Bozoğlu H 2006. Tepe ve Dal Almanın Baklanın (Vicia faba L) Çiçeklenme ve bakla Bağlama Durumuna Etkisi. OMÜ Ziraat Fakültesi Dergisi, 21(3): 296-302.

Topal N, Bozoğlu H. 2016. Determination of L-DOPA (L-3. 4dihydroxyphenylalanine) content of some faba bean (Vicia faba L.) genotypes. Journal of Agricultural Sciences 22: 145151.

Vioque J, Alaiz M, Girón-CJ. 2012. Nutritional and functional properties of Vicia faba protein isolates and related fractions. Food Chemistry, Vol 132, Issue 1, Pages 67-72 